Ann. Biol. anim. Bioch. Biophys., 1979, 19 (5), 1625-1629.

\title{
Diagnosis of the viability of early bovine embryos by fluorescence microscopy
}

\author{
par E. SCHILLING, D. SMIDT, B. SACHER, D. PETAC, S. EL KASCHAB \\ Instifut für Tierzucht und Tierverhalten (FAL), Moriensee, \\ D-3057 Neustadt 1, West Germany.
}

\begin{abstract}
Summary. A fluorescence microscopy technique using diacetylfluorescin (FDA) as a substrate has been tested for the evaluation of the viability of early bovine embryos. Five to 8-day old cattle embryos were incubated in PBS containing FDA concentrations of $1: 400000$ or $1: 800000$ for 3 to $5 \mathrm{~min}$ at room temperature. Embryos were then examined by reflected light fluorescence using a KP 490 and 520 barrier filter in a Zeiss Axiomat microscope. Their mitotic activity after $24 \mathrm{hrs}$ culture in vitro was used to determine their viability. After $3 \mathrm{~min}$ of incubation in the FDA medium, 85 p. 100 of the brilliantly fluorescing embryos showed mitoses after culture. None of the non-fluorescing embryos developed in vitro. Some embryos (about 6 p. 100) contained both dead and living cells as determined using the FDA test ; a few of these differentially reactive embryos were viable, but most of them were not. Short-term incubation of embryos in FDA medium probably did nof impair their development, and no teratogenic effects could be seen in 17 to 20 -day old rabbit feluses transferred after the FDA test.
\end{abstract}

\section{Introduction.}

The successful transfer of embryos depends mainly on their viability and developmental capacity. However, the viability of early embryonic stages is extremely difficult to predict. Culture techniques, whether in vivo or in vitro, demand a lot of time, and in order to make a reliable decision it is necessary to be able to see important morphological changes such as an increase in the number of blastomeres, the transition of morulae into blastocysts, or the hatching of the embryo from the zona pellucida. Following, the work of Renard ef al. (1977), it is easier to evaluate day-10 bovine embryos, and their developmental capacity can now be demonstrated by the metabolism of energy sources or enzymes in the culture medium. The common microscopic examination of morulae or blastocysts is said to be « a difficult and frustrating process 》 (Church and Shea, 1976), needing much practical experience. However, the technique can be used at the site of embryo recovery, and immediate transfer is therefore possible. Using this method, the main morphological criteria used for evaluating the viability of embryos are disorganization of the embryonic tissue and retarded development (Trounson et al., 1976 ; Shea et al., 1976 ; Wishart, 1977). Elsden et al. (1978) 
classified bovine embryos according to their morphology as « excellent, good, fair, and poor », and with this classification obtained pregnancy rates of 63, 58, 31 and 12 p. 100, respectively, thus indicating the uncertainty of microscopic assessment.

The aim of our studies was to improve the microscopic technique. To that end, we tested several fluorescent dyes. Acridinorange gave an excellent fluorescence of the nuclei, but was cytotoxic and the embryos did not develop after culture. Primulin was only faintly fluorescent, FITC stained mainly the zona pellucida and only slightly the blastomeres or trophoblast cells. We obtained better results by using 3', 6'-diacetylfluorescin (DFA). FDA is a non-fluorescent compound converted to a fluorescent compound upon contact with hydrolases, present only in living cells (Rotman ef al., 1966 ; Forstmaier, 1978). Our preliminary results lead us to believe that the FDA technique may be a better, more rapid test for assessing the viability and developmental capacity of early embryonic stages than normal microscopic examination (Schilling and Doepke, 1978).

\section{Material and methods.}

FDA dissolved in acetone $(1 \mathrm{mg} / \mathrm{ml})$ was added to PBS culture medium in concentrations of 1 : 400000 or $1: 800000$. Bovine embryos aged 5 to 8 days or rabbit embryos aged 2 to 4 days were incubated in these media for 3 to $5 \mathrm{~min}$ at room temperature. The optimal $\mathrm{pH}$ of the media was between 7.0 and 7.4. We found that incubation in Eagles medium or Ham's F 10 gave a less bright fluorescence. Immediately after incubation, the embryos were transferred to fresh PBS medium (or Eagles medium for rabbit embryos) and examined under reflected light fluorescence using a KP 490 and 520 barrier filter in a Zeiss Axiomat microscope. The use of a BG 12 and LP 500 barrier filter with reflected or transmitted light microscopy gave a less brilliant fluorescence. The viability and development of the treated embryos were determined by observation of their mitotic activity either after $24 \mathrm{hr}$ culture in vitro in PBS with 20 p. 100 fetal calf serum or, in the case of rabbit embryos, in Eagles medium or after transfer into rabbit oviducts. The technique of Tarkowski (1966) was used to prepare the mitotic figures.

\section{Results.}

After 3 min of incubation in the FDA medium, the fluorescence of the bovine embryos was either brilliant, nil, or, in a few cases (6 to 10 p. 100), either weak or with only some of the blastomeres fluorescing. The reaction was limited to the embryonic tissue, and the zona pellucida was always dark, as was the case with the mucin coat around the rabbit embryos. The blastomeres were more sharply outlined than when observed with normal light microscopy. The inner cell mass (embryonic node) of the blastocysts was usually more brilliantly fluorescent than the surrounding trophoblast cells. The results of the FDA test with bovine embryos are summarized in table 1 .

In the first column of that table, the 36 embryos which did not fluoresce after FDA incubation showed no mitotic activity after culture either. On the other hand, 
85 p. 100 of the embryos which did fluoresce brilliantly after recovery from the uterus showed mitosis ; in 15 p. 100 we failed to find mitosis. In addition, 5 out of 6 embryos, in which only a part of the blastomeres fluoresced, did not develop. Mitosis could be seen in only one of the 5 embryos with weak fluorescence. In 2 bovine blastocysts the zona of the embryonic node was dark, although the surrounding trophoblast cells were brightly fluorescent ; these embryos did not develop in vitro. We obtained similar results with the 2 to 4-day old rabbit embryos : those which did not fluoresce did not develop. There was about the same percentage of mitotic activity in fluorescing rabbit embryos as in bovine embryos.

TABLE 1

Fluorescence and mitotic activity of 5 to 9-day old bovine embryos after incubation in FDA

\begin{tabular}{|c|c|c|c|c|c|c|c|c|}
\hline \multirow{2}{*}{ Fluorescence } & \multicolumn{2}{|c|}{ Negative } & \multicolumn{2}{|c|}{ Brilliant } & \multicolumn{2}{|c|}{ Partly } & \multicolumn{2}{|c|}{ Weak } \\
\hline & + & - & + & - & + & - & + & - \\
\hline $\begin{array}{c}\text { Number of em- } \\
\text { bryos } \ldots \ldots \ldots\end{array}$ & 0 & 36 & 33 & 6 & 1 & 5 & 1 & 4 \\
\hline p. $100 \ldots \ldots \ldots$ & 一 & 100 & 85 & 15 & 16 & 84 & 20 & 80 \\
\hline
\end{tabular}

As mentioned previously, some embryos contained both dead and living cells, according to the FDA test. These partly reactive embryos (more frequent in rabbits) were viable in some cases. Although we do not yet have enough data, it is likely that embryo viability will depend on the percentage of living cells. This means that morula embryonic mortality probably results from a gradual loss of single blastomere viability. We also found that the reliability of the FDA test could be influenced by the age of the embryo. For example, when we treated rabbit embryos 60 to $84 \mathrm{hr}$ after ovulation, not only were the unfertilized eggs still fluorescent, but some of the 4 and 8cell embryos were slow to develop. In cattle, however, in which the time between recovery and ovulation is longer ( 5 to 9 days), neither the unfertilized eggs the slowly developing ones (4 to 16 cells) fluoresced.

Recently we demonstrated the practicability of the FDA test on frozen and thawed embryos. Faults during DMSO treatment, freezing or thawing can be revealed by a total or partial loss of the fluorescence after incubation, either immediately after thawing, or better after culture for $2 \mathrm{hr}$ in PBS. We found that those embryos did not develop further after a $24 \mathrm{hr}$ culture.

It is not likely that the short-term incubation of the FDA medium described here will impair their uterine development. Results of transfer into cattle are not yet available, but we base this conclusion on the observation that 85 p. 100 of the embryos developed in vitro after the FDA treatment. We have examined the developmental capacity of the embryos in vivo and the possible teratogenic effects of the FDA by seven transfer experiments in rabbits. Five control and 5 treated 16 to 32 -cell embryos were transferred into the left or right oviduct of each doe, and the animals were 
slaughtered between days 17 and 20 of pregnancy. More treated embryos developed into fetuses, and mortality after implantation was less than in the controls (table 2). The mortality rate before implantation was the same in both groups. Fetal malformations were not seen. We shall be able to determine whether the FDA treatment is teratogenic or not once ennough calves are produced from the incubated embryos.

TABLE 2

Development stage of transferred FDA-incubated rabbit embryos at days 17 to 20 of pregnancy

\begin{tabular}{|c|c|c|c|}
\hline $\begin{array}{c}\text { Embryos } \\
\text { transferred }\end{array}$ & Fetuses & $\begin{array}{l}\text { Loss after } \\
\text { implantation }\end{array}$ & $\begin{array}{l}\text { Loss before } \\
\text { implantation }\end{array}$ \\
\hline 35 treated $\ldots$. & 22 & 4 & 9 \\
\hline 35 controls..... & 16 & 11 & 8 \\
\hline
\end{tabular}

\section{Conclusion.}

These preliminary results suggest that the FDA test is a better technique than normal microscopic examination for evaluating the viability of early bovine embryos. In cases of embryonic disorganization, isolated blastomeres, contracted trophoblast, retarded stages, it is possible to determine rapidly and clearly whether the whole embryo will fluoresce or how many cells are still viable. It has been pointed out that all embryos which did not fluoresce after the FDA incubation failed to develop in culture, but that 85 p. 100 of the embryos with bright fluorescence showed mitotic division. Freezing techniques can probably be better assessed by using FDA incubation of thawed embryos. Finally, transfer experiments will prove whether the culture techniques can be replaced by the FDA test.

EEC Seminar on « Ovarian stimulation and egg quality in mammals », Luynes, France, octobre 1978.

Résumé. Une technique de microscopie à fluorescence utilisant la diacéthylfluorescéine (FDA) comme substrat a été testée pour évaluer la viabilité de jeunes embryons de bovins. Des embryons de 5 ou 8 jours d'âge ont été incubés dans le milieu PBS contenant des concentrations de 1 : 400000 ou $1: 800000$ de FDA pendant 3 à $5 \mathrm{mn}$, à la température de la pièce. Les embryons étaient examinés en lumière fluorescente réfléchie en utilisant un filtre KP 490 et 520 dans un microscope Zeiss Axiomat. La viabilité d'embryons traités était déterminée par leur activité mitotique après $24 \mathrm{~h}$ de culture in vitro. Après $3 \mathrm{mn}$ d'incubation dans le milieu FDA, 85 p. 100 des embryons fluorescents, montraient des mitoses après culture. Aucun des embryons non fluorescents ne se développait in vitro. Quelques embryons (environ 6 p. 100) contenaient à la fois des cellules mortes et vivantes d'après le test FDA; Ces embryons de réaction composite étaient dans quelques cas viables, mais la plupart d'entre eux ne l'étaient pas. La courte période d'incubation des embryons dans le milieu FDA n'a probablement pas altéré leur développement et aucun effet tératogène ne pouvait être vu sur des fœtus de lapin de 17-20 jours d'âge transférés après le test FDA. 


\section{References}

CHURCH R. B., SHEA B., 1976. Some aspects of bovine embryo transfer. Seminar on egg transfer in cattle, Cambridge, Dec. 10-12, 1975, 73-86.

ELSDEN R. P., NELSON L. D., SEIDEL G. E., 1978. Superovulating cows with follicle stimulating hormone and pregnant mare's serum gonadotrophin. Theriogenology, 9, 17-26.

FORSTMAIER I., 1978. Fluoreszenzmikroskopische Nachweisverfahren vitaler Keime in Trinkwasser, Fachz. Lab., 22, 379-385.

RENARD J. P., MÉNÉZO Y., SAUMANDE J., HEYMAN Y., 1977. Attemps to predict the viability of cattle embryos produced by superovulation. E.E.C. Conference Control of Reproduction in the cow, Galway, Sept. 27-30.

ROTMAN B., PAPERMASTER B. W., 1966. Membrane properties for living mammalian cells as studied by enzymatic hydrolysis of fluorogenic esters. Proc. Not. Acod. Sci., 55, 134-141.

SCHILLING E., DOEPKE H., 1978. A rapid diagnostic test for the viability of early cattle and rabbit embryos using diacetyl-fluorescin. Naturwissenschaffen, 65, 658.

SHEA B. F., HINES D. H., LIGHTFOOD D. E., OLLIS G. W., OLSON S. M., 1976. The transfer of bovine embryos EEC Sem. on egg transfer in cattle, Cambridge, Dec. 10-12, 1975, 145-158.

TARKOWSKI A. K., 1966. An air-drying method for chromosome preparation from mouse eggs. Cytogenetics, 5, 394-400.

TROUNSON A. O., WILLADSEN S. M., ROWSON L. E. A., 1976. The influence of in vitro culture and cooling on the survival and development of cow embryos. J. Reprod. Fert., 47, 367-370.

WISHART, D. F., 1977. Synchronization of cestrus in heifers using steroid (SC 5914, SC 9800 and SC 21009) treatment for 21 days. Theriogenology, 8, 249-269. 